\title{
Turkiseläinten lanta ohran kasvinravitsemuksessa
}

\author{
Petri Kapuinen
}

MTT, Kasvintuotannon tutkimus, 21500 Piikkiö, petri.kapuinen@mtt.fi

\section{Tiivistelmä}

Minkin virtsaa, sontalietettä ja ketun lietelantaa sellaisenaan ja eri tavoin jalostettuna tutkittiin ohran typen lähteenä Jokioisilla vuonna 2012 aitosavella toteutetussa kenttäkokeessa. Minkin virtsa ja sontaliete olivat peräisin häkkikanalan kaltaisesta turkiseläinten hallikasvattamosta. Tässä kasvatusjärjestelmässä turkiseläinten lanta voidaan kerätä ilman kuivikkeita ja typen tappiot ovat hyvin pienet suhteessa perinteisen varjotalokasvatuksen kuivikelannasta syntyviin. Näin kerätyssä turkiseläintenlannassa typen ja fosforin pitoisuussuhde ei oleellisesti poikkea esimerkiksi sianlietelannan vastaavasta. Jalosteet olivat sontalietteestä separoitu kuivaosa ja nesteosa sekä kompostoimattomasta ja kompostoidusta kuivaosasta valmistetut pelletit. Tuotteita käytettiin $90 \mathrm{~kg} /$ ha liukoista typpeä vastaava määrä analysoituna 1:60 vesiuutolla lukuun ottamatta pellettejä, joissa kokonaistypen annos $170 \mathrm{~kg} / \mathrm{ha}$ muodostui rajoittavaksi tekijäksi, ja niitä käytettiin tätä kokonaistyppimäärää vastaava annos. Käyttömäärät olivat 6,5-11,2 t/ha. Saatua satoa verrattiin kylvölannoituksen yhteydessä sijoitetun mineraalilannoitteen typen tuottamaan satoon eri typpitasoilla tuotetun typen tuotantofunktion avulla.

Turkiseläinten lannan lisäksi vastaavissa käsittelyissä ei käytetty mineraalilannoitteen typpeä, mikä johti siihen, että sadot jäivät selvästi huonommiksi kuin sijoitetulla mineraalilannoitteen typellä. Merkittävä osuus tästä johtui siitä, että turkiseläinten lanta ja sen jalosteet levitettiin kiinteiden jakeiden tapauksessa hajalevitystä ja nestemäisten jakeiden osalta letkulevitystä imitoiden, jota seurasi tunnin kuluttua multaus joustopiikkiäkeellä. Koska typpeä ei annettu optimaaliseen paikkaan, ohra kärsi typen pulasta kasvukauden alussa.

Suomalainen lanta-analyysimenetelmä ja lannoitevalmistelainsäädännön mukaisesta liukoisen typen analyysimenetelmästä modifioitu analyysimenetelmä 1:60 vesiuutolla 1:5 sijasta antavat keskenään samankaltaisen kuvan turkiseläinten lannan liukoisen typen tuotantovaikutuksesta. Parhaiten näillä menetelmillä analysoidun liukoisen typen pitoisuus ennusti virtsan, separoidun kuivaosan ja kompostoitujen pelletien typen tuotantovaikutusta. Sato oli näitäkin jakeita käytettäessä kuitenkin 30 40 \% pienempi kuin samalla määrällä mineraalilannoitteen typpeä. Turkiseläinten lantaa ja sen jatkojalosteita ei voida suositella ohran kaltaisten kasvien ainoaksi typen lähteeksi kuten tässä kokeessa, vaan sen ohella on käytettävä kylvön yhteydessä sijoittamalla annettavaa merkittävä määrä, ehkä 2/3, starttityppeä. Tällöin fosforimäärät jäävät varsin kohtuullisiksi varsinkin jos kokonaisfosforista otetaan huomioon vain 40 \%. Tällöin turkislannan määrä jää varsin pieneksi ja sopivan levitysmenetelmän löytäminen on uusi haaste.

Asiasanat: minkinlanta, ketunlanta, turkislanta, virtsa, pelletti, hallikasvatus, ohra, typpi, starttityppi analyysimenetelmät 


\section{Johdanto}

Kapuinen (2014) on tarkastellut turkiseläinten lannan käyttöön liittyviä kysymyksiä porkkanalla toisaalla tässä julkaisussa. Sama viitekehys koskee hyvin pitkälle turkiseläinten lantojen käyttöä myös viljakasveilla, kuten ohralla. Ohran ravinteiden otto kuitenkin keskittyy hyvin voimakkaasti kasvukauden alkuun, ja erityisesti typen riittävä saanti kasvukauden alussa on hyvin kriittinen tekijä sadonmuodostuksessa. Orgaanisia lannoitevalmisteita voidaan käyttää osana viljakasvien typpilannoitusta tavanomaisessa tuotannossa, kun riittävän nopeasta typen saannista kasvukauden alussa huolehditaan riittävällä mineraalilannoitteena annettavalla starttilannoituksella, joka annetaan sijoittamalla kylvölannoituksen yhteydessä. Suomalaisessa hektisessä kasvukaudessa sijoittamalla tehdyn kylvölannoituksen merkitys viljakasvien sadonmuodostuksessa on keskeinen. Hajalevitys ei mahdollista riittävän nopeaa typen saantia, koska ravinteet joutuvat hajalevityksessä ja multauksessa väärään paikkaan, vaikka typen tappiot ammoniakkina olisivatkin kohtuulliset.

Ohralla käytettävä typen määrä on selvästi suurempi suhteessa fosforin määrään kuin porkkanalla (MMM 2007, 2008). Ohran kasvinravinteiden lähteeksi sopii siten parhaiten ne turkiseläinten lannasta johdetut komponentit, joiden fosforipitoisuus on pieni suhteessa typpipitoisuuteen. Ohran viljelyssä tarkoituksenmukaisimpia häkkikanalan kaltaisessa turkiseläinten hallikasvatuksessa syntyviä lannan muotoja, jotka esitellään tarkemmin muualla tässä julkaisussa (Kapuinen 2014) ovat virtsa, sontaliete ja separoitu nesteosa. Ohralle on myös oleellista lannan sijoitus, jotta typen saanti ei muodostuisi kasvua rajoittavaksi tekijäksi kasvukauden alussa. Nykyteknologia kuitenkin tarjoaa mahdollisuuden sijoittaa ainoastaan nestemäisiä lantoja. Kiinteiden pelletöimättömien tai rakeistamattomien jalosteiden sijoittamiseen ei ole näköpiirissä ratkaisua. Pelletöityjä ja rakeistettuja lantajalosteita voidaan periaatteessa sijoittaa samantyyppisillä laiteilla kuin mineraalilannoitteitakin, mutta lannasta jalostettujen lannoitevalmisteiden ravinnepitoisuudet ovat turkiseläintenkin lannasta johdettuina pienet ja siten niiden levitysmäärät suuret (t/ha). Esimerkiksi tässä tutkimuksessa minkinlantapellettejä levitettiin 6,5 - 7,0 t/ha. Kun lisäksi orgaanisten lannoitevalmisteiden tilavuuspaino on selvästi pienempi kuin mineraalilannoitteiden ja sijoituslaitteiden annostelulaitteet toimivat viimekädessä tilavuusperusteisesti, olemassa oleva maatilojen mineraalilannoitteiden levitykseen tarkoitetut koneet ei sovi käyttötarkoitukseen, vaikka levitettävä materiaali annostelulaitteiston ilman ongelmia läpäisisikin. Tilavuutena tässä tutkimuksessa käytettiin minkinlantapellettejä 8,6 - 9,0 $\mathrm{m}^{3} / \mathrm{ha}$. Levitettävissä olevat määrät yksikertaisesti jäävät liian pieniksi. Perinteisen varjotaloissa tuotettu turkiseläinten kuivikelannan käyttömahdollisuudet ohranviljelyssä rajoittuu lähinnä muuhun kuin typpilannoitukseen.

Vaikka turkiseläinten lannan ja siitä johdettujen lannoitevalmisteiden ominta käyttöaluetta on juuri sellaisten kasvien lannoitus, jotka käyttävät typpeä runsaasti vasta kasvukauden lopussa, tarvitaan niille myös muita käyttökohteita, koska hitaasti typpeä käyttävien kasvien osuus viljelypintaalasta on pieni. Viljojen, öljykasvien ja nurmikasvien osuus viljelypinta-alasta oli 1222000 ha eli 83,7 \% vuonna 2012 (Tietohaarukka 2012). Soveltuvista volyymikasveista tärkein on ohra, jota viljeltiin 2012503000 ha. Se tarjoaa merkittävän levityspinta-alan turkiseläinten lannan ravinteiden tehokkaaseen hyödyntämiseen. Kaudella 2011/2012 myytyjen 1,7 miljoonan ketunnahan tuottamisesta syntyy periaatteessa 3,4 miljoonaa $\mathrm{kg}$ typpeä ja $0,765 \mathrm{~kg}$ miljoonaa $\mathrm{kg}$ fosforia. Vastaavana aikana myytyjen 1,1 miljoonan minkinnahan tuottamisesta syntyi vastaavasti 1,155 miljoonaa kg typpeä ja 0,275 miljoonaa kg fosforia (Rekilä ym. 2010). Ketun ja minkinnahkojen tuotannosta syntyi siten yhteensä 4,555 miljoonaa kg typpeä ja 1,04 miljoonaa kg fosforia.

Kalenterivuodessa voidaan ns. nitraattiasetuksen (VN 2000) mukaan levittää 170 kg/ha kokonaistyppeä. Ketun ja minkinlannan levittämiseen tarvittaisiin siis noin 27000 ha, joka on runsas prosentti Suomen peltoalasta, 2248000 ha vuonna 2012 (Tietohaarukka 2013). Kun lannan mukana tuleva fosfori jaetaan tälle levitysalalle, kokonaisfosforin määräksi tulee $51,8 \mathrm{~kg} / \mathrm{ha}$, josta nykyinen maatalouden ympäristötukijärjestelmä (MMM 2007, 2008) laskee kasveille käyttökelpoiseksi 40 \% eli 21,7 $\mathrm{kg} / \mathrm{ha}$. Se vastaa määrä, jonka voisi antaa ohralle vuosittain maan fosforiluvun ollessa välttävä. Viljakasveilla lantaa ja orgaanisia lannoitevalmisteita ei kuitenkaan kannata käyttää näin, vaan vähintään puolet liukoisen typen annoksesta tulisi antaa kylvölannoituksen yhteydessä sijoittamalla (Kapuinen ym. 2012). Tässä tutkimuksessa käytetyn minkin sontalietteessä 1:60-vesiuuton mukainen liukoisen typen osuus kokonaistypestä oli 87 \%, joka johtaisi hyvin suureen liukoisen typen annokseen 148 $\mathrm{kg} / \mathrm{ha}$ levitettäessä kokonaistypen perusteella. Jotta lannasta tai orgaanista lannoitevalmisteesta tulevan liukoisen typen osuus sen kokonaismäärästä pysyisi kohtuullisena, levitysmäärän pitäisi olla noin 
kolmannes siitä, mitä sitä saisi käyttää kokonaistyppimäärän perusteella. Fosforiannos pieneni vastaavasti, jolloin tarvittaisiin pikemminkin fosforin lisälannoitusta mineraalilannoitteena. Kasvintuotannon kannalta järkevässä lannankäytössä ketun ja minkin lannan levittämiseen tarvittava peltoala on siten noin 90000 ha, joka olisi jo merkittävä osuus esimerkiksi ohran viljelypinta-alasta.

Valtaosa turkiseläinten nahoista tuotetaan kuitenkin edelleen varjotaloissa (Rekilä ym. 2010). Pääosa turkiseläinten lannasta on siten kuivikelantaa. Varjotaloista tulevan turkiseläinten lannan määräksi arvioitiin $300000 \mathrm{~m}^{3}$, jolloin minkkejä oli $17 \%$ ja kettuja $37 \%$ enemmän kuin 2012 (MMM 2002, ProFur 2012). Nykyinen määrä voisi siten olla noin $200000 \mathrm{~m}^{3}$. Kapuinen (2014) tarkastelee varjotalojen ravinnetappioita ja vertailee niissä kerätyn lannan ja hallikasvatuksessa kerätyn lannan ravinnepitoisuuksien eroja sekä potentiaalisia eroja käytössä tarkemmin muualla tässä julkaisussa. Sen käyttö poikkeaa ratkaisevasti tässä artikkelissa käsitellystä hallikasvatuksessa kerätyn lannan käytöstä, koska sen käyttöä rajoittaa lähinnä fosforimäärä. Ohralle ympäristötukijärjestelmässä (MMM 2007, 2008) viidessä vuodessa sallittu $70 \mathrm{~kg} /$ ha kasveille käyttökelpoista fosforia perussatotasolla saadaan tilastokeskiarvon (VP 2012) mukaisesta turkiseläinten lannasta levittämällä sitä 10,9 t/ha, jolloin saadaan 124 kg/ha kokonaistyppeä ja vain 32 kg/ha Viljavuuspalvelun Oy:n lanta-analyysimenetelmän mukaista liukoista typpeä.

Tutkimuksen tavoitteena oli selvittää turkiseläinten lannan ja sen johdannaisten soveltuvuus ohran typen lähteeksi ja yleensä sen lannoitukseen sekä niiden liukoisen typen oikeaa arvostusperustetta.

\section{Aineisto ja menetelmät}

Turkiseläinlantojen ja niistä valmistettujen lannoitevalmisteiden typen tuotantovaikutusta ohralla (Annabell, itäviä $500 \mathrm{kpl} / \mathrm{m}^{2}$ ) tutkittiin vuonna 2012 kenttäkokeessa Jokioisissa runsasmultaisella aitosavella. Käsittelyiden jälkivaikutus tutkittiin samalla koekentällä vuonna 2013.

Koemuoto oli satunnaistettujen lohkojen koe, jossa lohkoihin satunnaistettiin ensin mineraalilannoitteella lannoitettavat typpitasot ja turkiseläinten lannoilla ja niistä johdetuilla tuotteilla lannoitetut pääruudut. Sen jälkeen N-tasot satunnaistettiin keskenään ja toisaalta turkiseläinlanta ja niistä johdettujen tuotteiden käsittelyt keskenään. Koealue tasausäestettiin 21.5., kylvömuokattiin vaakatasojyrsimellä kylvösyvyyteen lohkojen suuntaisesti poikki ruutujen ja koe mitattiin pellolle 23.5. Siltä otettiin kokooma maanäytteet $20 \mathrm{~cm}: n$ pintakerroksesta lohkoittain. Maanäytteistä määritettiin liukoisen typen pitoisuus ja viljavuus. Maan johtokyky oli 1,5 dS/m, pH 6,2, Ca 3125 mg/l, P 5,9 mg/l, K 355 mg/l, Mg 778 mg/l ja S 11,3 mg/l. Maan happamuus oli tyydyttävä ja fosforiluku oli vain välttävä. Koealueen kylvömuokkaus viimeisteltiin ennen lantojen ja lannoitevalmisteiden käsin tehtyä levitystä joustopiikki-varpajyrä-äkellä (Potila 340). Lannat ja lannoitevalmisteet mullattiin joustopiikkiäkeellä noin tunnin kuluttua niiden levityksestä koeruutujen suuntaisesti. Koealue kylvettiin ruuduittain 25.5. Ohra orastui noin 8.6. Ensimmäiset maanäytteet otettiin 7.-8.6. ja toiset 20.-21.6. Rikat torjuttiin 4.7 (Hankkijan MCPA 1,5 l/ha, Expess 50T 1,25 tabl./ha, BF kiinnite 0,1 l/ha, 200 l/ha vettä). Kolmannet maanäytteet otettiin 10.-11.7. Koeruudut puitiin 20.9. Sadonkorjuun jälkeen otettiin maanäytteet 25.9. Osasta käsittelyitä otettiin 1.-2.11. maanäytteet kerroksittain mahdollisen liukoisen typen kulkeutumisen syvempiin kerroksiin toteamiseksi. Koealue kynnettiin 9.11., jotta sille voitiin perustaa jälkivaikutuskoe vuonna 2013.

Kokeessa käytetyt lannat ja lannoitevalmisteet olivat koejäsenittäin: 1) minkin virtsa (11,2 t/ha), 2) minkin sontaliete (8,2 t/ha), 3) minkin sontalietteestä separoitu nesteosa (7,1 t/ha), 4) minkin sontalietteestä separoitu kuivaosa (11,1 t/ha), 5) edellisestä koejäsenestä 4 kompostoimalla saatu kompostoitu minkin sontalietteestä separoitu kuivaosa (9,6 t/ha), 6) koejäsenestä 4 valmistettu pelletti (6,5 t/ha), 7) koejäsenestä 5 valmistettu pelletti (7,0 t/ha) ja 8) ketunlietelanta (8,9 t/ha).

Koejäseniä 1-5 ja 8 levitettiin ennakkonäytteistä 1:60 vesiuutolla määritetyn liukoisen typen pitoisuuden perusteella määrä, jolla olisi pitänyt tulla 90 kg/ha liukoista typpeä. Koejäseniin 1-4 ja 8 tuli levityksen yhteydessä otettujen näytteiden perusteella lähes tavoitteen mukainen määrä liukoista typpeä, 81,1 - 90,9 kg/ha määritettynä 1:60 vesiuutolla. Koejäseneen 5 tuli liukoista typpeä 43,9 kg/ha. Koejäsenissä 6-7 kokonaistyppiraja $170 \mathrm{~kg} / \mathrm{ha}$ rajoitti levitysmäärää. Liukoisen typen määrä oli ennakkonäytteiden mukaan 49,0 - 65,7 kg/ha ja levitysnäytteiden perusteella vain 39,3 - 53,9 kg/ha.

Kokeessa oli varsinaisten lanta- ja lannoitevalmistekäsittelyiden lisäksi N-tasot 0, 30, 60, 90, 120 ja 150 kg N/ha. N-tasoissa käytetty mineraalilannoite oli Pellon Y6 (15-7-13). Perustasossa tuli 90 $\mathrm{kg} \mathrm{N} / \mathrm{ha}, 43 \mathrm{~kg}$ P/ha ja $78 \mathrm{~kg} \mathrm{~K} / \mathrm{ha}$. Typpitasojen lannoitteen ravinnesuhteet valittiin niin, että ainoastaan typpi oli niistä satoa rajoittava ravinne. 
$\mathrm{N}$-tasojen satotulosten perusteella laskettiin mineraalilannoitteen typen vaikutus ohran satoon (satoennuste). Turkiseläinten lannoilla ja niistä johdetuilla lannoitevalmisteilla saatuja satoja verrattiin vastaavalla mineraalilannoitteen typpimäärällä saatuun satoon turkiseläinten lantojen ja niistä johdettujen lannoitevalmisteiden liukoisen typen pitoisuus ollessa määritetty kolmella eri menetelmällä. Liukoisen typen pitoisuuden määrittämisessä käytettiin lannoitevalmistelainsäädännön mukaista 1:5vesiuuttoa (MMM 2011), siitä modifioitua 1:60 vesiuuttoa ja Viljavuuspalvelu Oy:n käyttämää lantaanalyysimenetelmää. Eri menetelmien tuottamia liukoisen typen pitoisuuksia verrattiin toisiinsa ja arvioitiin eri menetelmillä määritettyjen liukoisen typen pitoisuuksien käyttökelpoisuutta typen tuotantovaikutuksen kuvaajana. Pellettien liukoisen typen pitoisuus analysoitiin myös 1:100-vesiuutolla.

Vuoden 2012 ohrakenttäkoe perustettiin kylvämällä se uudelleen ohralla (Harbinger, itäviä 500 $\mathrm{kpl} / \mathrm{m}^{2}$ ) 16.5. vuonna 2013 siten, että turkiseläintenlantakäsittelyt vain kylvettiin mutta typpitasoihin 30, 60 ja $90 \mathrm{~kg} \mathrm{~N} / \mathrm{ha}$ annettiin vastaava typpilannoitus. Sitä suurempia typpitasoja vastaavat ruudut jätettiin lannoittamatta. Koealue oli tasausäestetty 8.5. Kylvömuokkaus tehtiin kylvöpäivänä vastaavalla tavalla kuin vuonna 2012. Sitä ei kuitenkaan viimeistelty joustopiikkiäkeellä. Rikkakasvien torjunta 19.6. Ohrakoe puitiin 4.9. Turkiseläinten lantakäsittelyistä saatuja satoja verrattiin näistä typpitasoista saadun tuotantofunktion mukaiseen satoon ja määritettiin sitä vastaava mineraalilannoitteena annettu typpimäärä.

\section{Tulokset ja tulosten tarkastelu}

Lannoittamattoman käsittelyn sato oli noin $1300 \mathrm{~kg} / \mathrm{ha}$. Suurin sato saavutettiin suurimmalla typpitasolla $150 \mathrm{~kg} / \mathrm{ha}$, mutta mitään oleellista sadon lisäystä ei saatu viimeisellä $30 \mathrm{~kg}$ N/ha. Tavoitetason 90 $\mathrm{kg} \mathrm{N} / \mathrm{ha}$ sato osui hyvin lineaariselle alueelle (kuvio 1, a). Tavoitetason mukainen sato oli $4487 \mathrm{~kg} / \mathrm{ha}$. Kenttäkokeen konstruointi onnistui tässä mielessä täydellisesti.

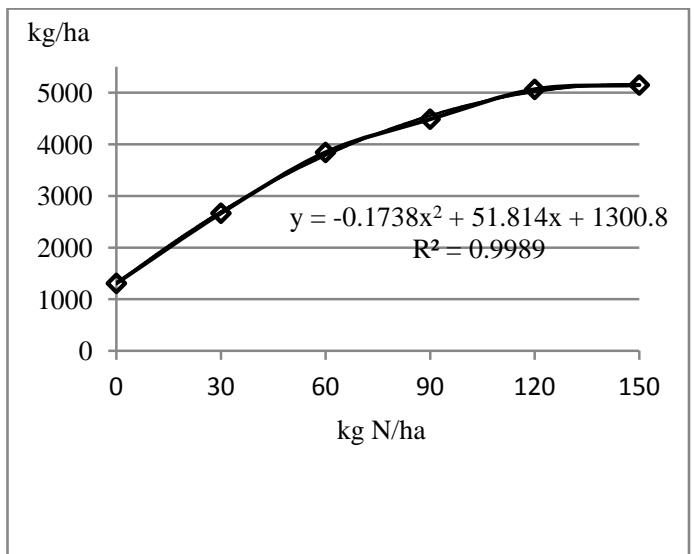

a

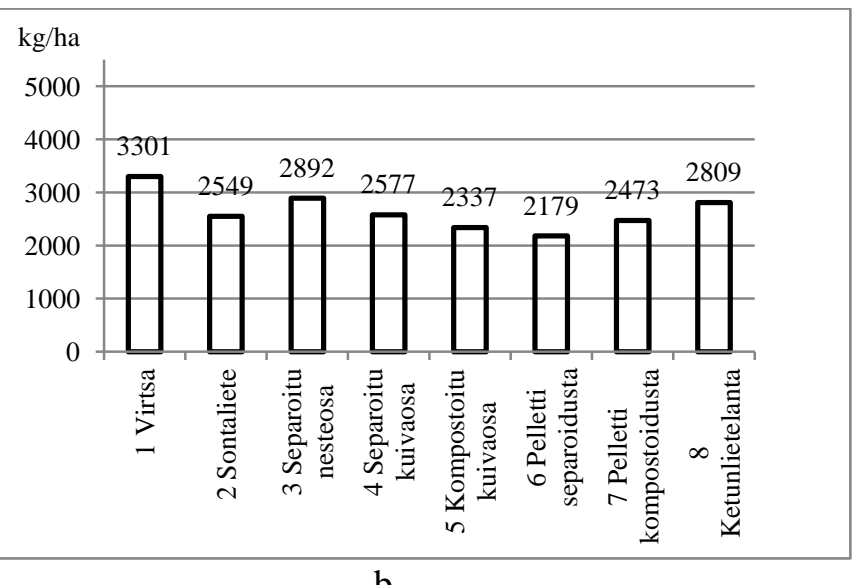

b

Kuvio 1. Mineraalilannoitteen (a) sekä turkiseläinten lannoilla ja niistä johdetuilla lannoitevalmisteilla saadut normisadot (b) (koejäsenet kts. Aineisto ja menetelmät)

Turkiseläinten lannoilla saavutettiin sato (Kuvio 1, b), joka oli selvästi alle tavoitetason (90 N kg/ha) mukaisen sadon, vaikka liukoisen typen määrät olivat useimmilla koejäsenillä lähellä tavoitetasoa. Suurimpana syynä tähän oli se, että kokeessa ei käytetty lainkaan täydennyslannoitustyppeä kylvön yhteydessä, jolloin ohra kärsi kasvukauden alussa typen puutetta. Turkiseläinten lannoista virtsalla saatiin paras mitattu sato, $3301 \mathrm{~kg} / \mathrm{ha}$. Tulosten perusteella kokeessa käytetty lannankäyttöstrategia, jossa käytettiin ainoastaan turkiseläinten lantaa, ei sovellu käytännön ohranviljelyyn, koska satotasot jäävät pieneksi. Se kuitenkin paljastaa erilaisten turkiseläinlantojen liukoisen typen tuotantovaikutuksen. Täydennyslannoituksen tarve voidaan arvioida näiden tulosten perusteella. Tuloksen voidaan olettaa olevan lähes sama kaikilla kotimaisilla kevätkylvöisillä viljalajeilla, mutta ohralla typen käyttökelpoisuuden erot näkyvät parhaiten.

Vaikka kokeessa mineraalilannoitteella saavutettiin samoista käsittelyistä kaikissa kerranteissa lähes sama sato, vaihtelu turkiseläinten lantaa saaneiden käsittelyiden sadoissa kerranteittain oli selvästi suurempi (tietoja ei näytetty). Se viittaa siihen, että turkiseläinten lanta ainakin pintaan levitettynä saattoi aiheuttaa suurta vaihtelua kasvupaikan maan ominaisuuksista riippuvaa vaihtelua. Vastaava 
vaihtelu näkyi myös sadon laatutekijöissä. Lajitteiden I + II summa jäi turkiseläinten lantaa käytettäessä pääsääntöisesti alle 85 \% (tietoja ei näytetty). Vastaavasti IV-jakeen osuus on pääsääntöisesti yli 5 \%. Tavoitetason mukaisella typpiannoksella mineraalilannoite tuotti nämä mallasohran laatutekijärajat täyttävän sadon.

Lannoittamattoman käsittelyn raakavalkuaispitoisuus oli 10,5\%, josta se laski runsaaseen 9 \%:iin tasoilla $30-60 \mathrm{~kg} \mathrm{~N} / \mathrm{ha}$ nousten lähes lineaarisesti tasolle $150 \mathrm{~kg} \mathrm{~N} / \mathrm{ha}$ saavuttaen pitoisuuden 11,0 \% (tietoja ei näytetty). Turkiseläinten lannoilla tuotettiin ohraa, jonka raakavalkuaispitoisuus oli 9,7 - 10,4 \%. Se oli jonkin verran korkeampi kuin vastaavalla määrällä mineraalilannoitteen typpeä saavutettiin. Pääsääntöisesti pieni sato indikoi suurta raakavalkuaispitoisuutta, mikä selittyy sillä, että lantojen ja lannoitevalmisteiden typen vaikutus myöhästyi hajalevityksen takia.

Lannoista ja lannoitevalmisteista Viljavuuspalvelu Oy:n lanta-analyysi ja 1:60-vesiuutolla analysoidut liukoisen typen pitoisuudet olivat lähes samat. Sen sijaan lannoitevalmistelainsäädännön mukaisella 1:5-vesiuutolla analysoidut liukoisen typen pitoisuudet ovat selvästi pienemmät kuin kahdella muulla analyysimenetelmällä analysoidut. Ero on pienin nestemäisillä lannoilla kuten minkinvirtsa ja sontaliete. 1:5-vesiuutolla määritetyn liukoisen typen pitoisuus on sitä pienempi suhteessa muihin, mitä kuivemmasta tuotteesta on kysymys. Tämä on osoitus siitä, että 1:5-uuttosuhde on liian tiukka, ja sen antama tulos reagoi voimakkaasti tuotteen kuiva-ainepitoisuuteen. Ero on suurin kuivilla lannoitevalmisteilla kuten pelleteillä, jotka lannoitevalmistelainsäädännön (MMM 2011) perusteella kuitenkin analysoitaisiin 1:100-vesiuutolla. 1:100-vesiuutto tuotti pelleteistä 7 - $15 \%$ suuremman ammoniumtyppipitoisuuden kuin 1:60-vesiuutto, joten myös 1:100-vesiuutto antaa realistisen kuvan pellettien liukoisen typen tuotantovaikutuksesta. Pellettien liukoisen typen analyyseissa ratkaisevaa on näytteiden esikäsittely, murskaaminen tai murskaamatta jättäminen ennen analyysia.

Nitraattityppeä oli vain kompostoiduissa lannoissa ja lannoitevalmisteissa. Sontalietteessä ja pelleteissä oli merkittävä määrä orgaanisia vesiliukoisia typpiyhdisteitä. Muutoin liukoinen typpi on pääasiassa ammoniummuodossa. Liukoisen typen komponenteista nitraatti on nopeavaikutteisin ja orgaaniset vesiliukoiset typpiyhdisteet hidasvaikutteisimmat. Vaikka lanta-analyysin ja 1:60-vesiuuton mukaisen liukoisen typen pitoisuudet antavat keskenään samanlaisen satoennusteen, satoennuste suhteessa vastaavalla mineraalilannoitteen typen liukoisen typen annoksen antamaan satoon ei ole hyvä. Sato saattaa olla jopa 75 \% pienempi kuin sen liukoisen typen annoksen perusteella pitäisi olla, ja ero vaihtelee voimakkaasti riippuen käytetystä tuotteesta (Kuvio 2). Parhaimmillaankin sato on noin $25 \%$ pienempi kuin sen ennusteen perusteella pitäisi olla. Tulosten perusteella näyttäisi siltä, että liukoisen typen määrän perusteella saadaan paras ennuste, jos kyseessä on virtsa tai kompostoitu turkiseläinten lantatuote. Tämä ei näytä suoranaisesti liittyvän liukoisen typen eri komponenttien osuuteen, vaan johonkin muuhun tekijään.

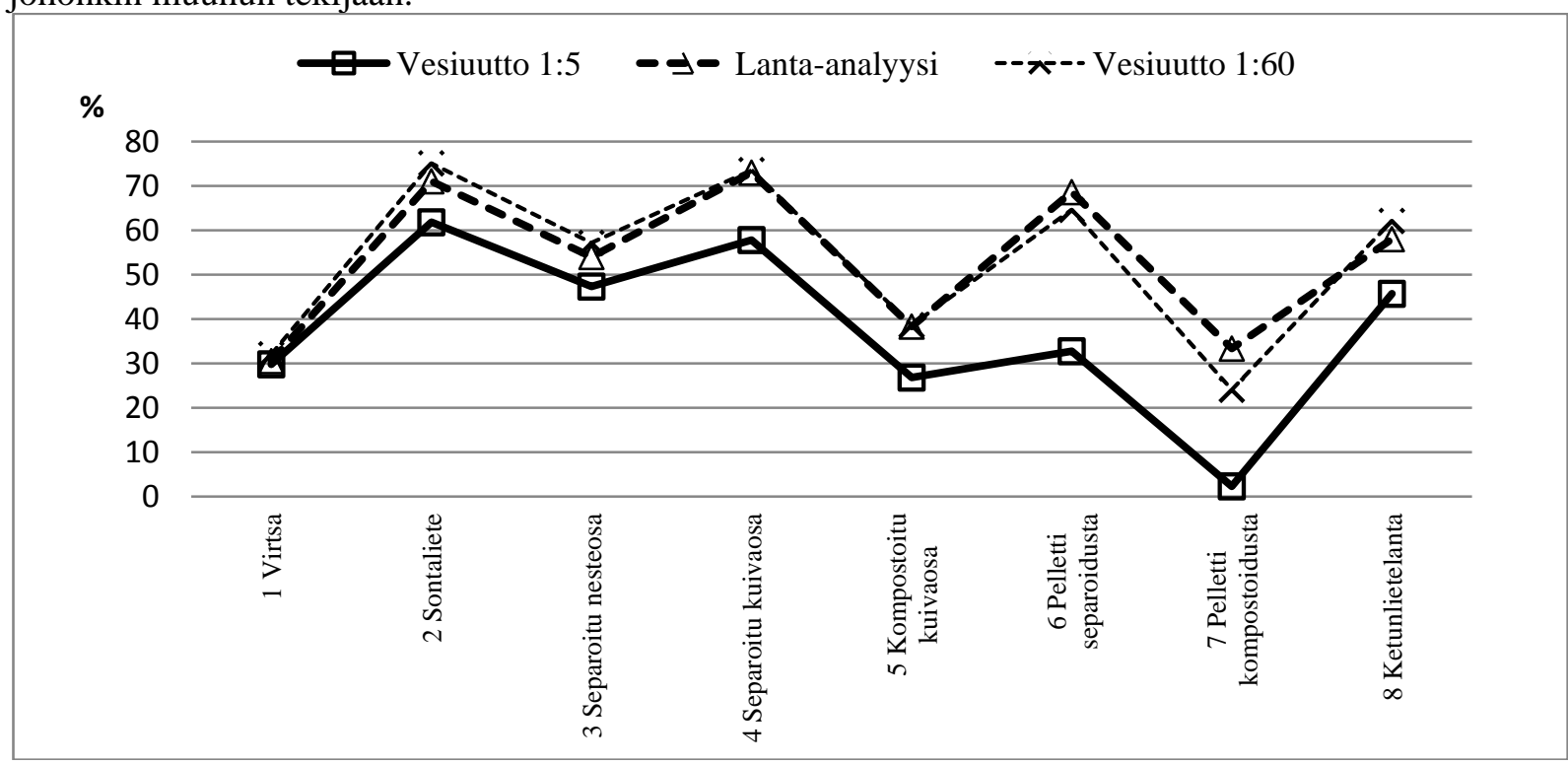

Kuvio 2. Sadon aleneman suhteessa vastaavan mineraalilannoitteen typen annoksen tuottamaan vertailtaessa liukoisen typen määrää $(\mathrm{kg} / \mathrm{ha})$ analysoituna turkiseläinten lannoista ja niistä valmistetuista lannoitevalmisteista kolmella eri menetelmällä 
Sekä lanta-analyysimenetelmä, 1:60 että 1:100 (pelletit) -vesiuutto antavat realistisen kuvan turkiseläinten lantojen ja niistä johdettujen lannoitevalmisteiden liukoisen typen pitoisuudesta, ja se, että niiden perusteella ei saada hyvää ennustetta ohrasadon määrästä, johtuu siitä, että liukoisen typen käyttökelpoisuus ohralle on selvästi huonompi, jos ne levitetään pintaan ja mullataan kylvömuokkauksen yhteydessä kuin, että se sijoitettaisiin. Sen tähden ohran kaltaisilla kasveilla on käytettävä levitysstrategiaa, jossa pintaan levitettävistä lannoista ja lannoitevalmisteista tulee vain noin kolmannes puolet liukoisen typen määrästä ja loppu tulee mineraalilannoitteesta.

Keskeisin syy siihen, että ohralla esiintyi typenpuutetta kasvukauden alussa, oli se, että maan nitraatti- mutta myös ammoniumtyppipitoisuudet jäivät selvästi pienemmiksi käytettäessä pelkästään turkiseläinten lantaa mineraalilannoitteen sijasta, vaikka liukoisen typen annos oli lähes sama (tietoja ei näytetty). Kahden viikon kuluttu kokeen perustamisesta tavoitetason mukaisen typpiannoksen saaneen mineraalilannoitekäsittelyn maan ammoniumtypen pitoisuus oli noin $13 \mathrm{mg} / \mathrm{l}$ ja jyrkässä laskussa. Samanaikaisesti suurin turkiseläintenlantakäsittelystä mitattu pitoisuus oli vain $6 \mathrm{mg} / \mathrm{l}$, sekin laskussa. Poikkeuksen tähän kuvioon tekee ketun lietelanta, jota vastaavassa käsittelyssä ammoniumtypen pitoisuus oli alussa pieni ja saavutti huippunsa vasta noin kuukauden kuluttua perustamisesta. Seitsemän viikkoa perustamisesta ammoniumtyppipitoisuudet olivat kevään taustatasossa kaikissa mitatuissa käsittelyissä.

Mineraalilannoitteella suurin typpitaso, josta otettiin maanäytteitä liukoisen typen pitoisuuden määrittämiseksi kasvukauden aikana, oli 90 kg N/ha. Nitraattityppi oli hallitseva mineraalilannoitetyppikäsittelyssä, joka oli saanut 90 kg N/ha. Siinä käsittelyssä ammoniumtyppi nitrifioituu nitraatiksi ja nitraattipitoisuus säilyi lähes vakiona, 20 - 22 mg/l, neljä viikko kylvöstä ja alkoi laskea vasta sen jälkeen. Tämä on ohran tasapainoisen typen saannin kannalta oleellista. Ammonium- ja nitraattitypen pitoisuus oli tässä käsittelyssä kaksi viikko perustamisesta $34 \mathrm{mg} / \mathrm{l}$ ja jyrkässä laskussa. Se vastaa noin $70 \mathrm{~kg} \mathrm{~N} / \mathrm{ha}$, mikä oli hyvin sopusoinnussa perustamisessa annetun $90 \mathrm{~kg} \mathrm{~N} / \mathrm{ha}$ ja maan pitoisuuuden 6 mg/l maata perustettaessa kanssa. Turkiseläinten lantaa saaneiden käsittelyiden maan nitraattipitoisuus oli enimmillään $14 \mathrm{mg} / \mathrm{l}$ suurimman sadon tuottaneella virtsalle. Niille oli tyypillistä, että nitraattitypen pitoisuus saavutti huippunsa vasta neljä viikkoa kylvöstä. Tämä aiheuttaa typen puutteen kasvukauden alussa ja sadonalennuksen. Hyvä ohrasato voidaan saavuttaa vain kasvattamalla lannan tai lannoitevalmisteen nitraattitypen osuutta liukoisesta typestä ja sijoittamalla se kasvin kannalta oikeaan paikkaan eli sinne minne mineraalilannoitekin sijoitetaan.

Maan liukoisen typen kokonaistypen pitoisuus 7 - 10 mg/l oli jo kolmannella näyteenottokerralla heinäkuun puolessa välissä hyvin pieni riippumatta annetusta typpimäärästä. Ero lannoittamattoman ja suuriman typpitason mukaisissa käsittelyissä oli vain $3 \mathrm{mg} / \mathrm{l}$, mikä vastaa määrää $6 \mathrm{~kg}$ N/ha. Lannoittamattoman ja tavoitetason $90 \mathrm{~kg}$ N/ha mukaisten käsittelyiden välinen ero oli vain $2 \mathrm{mg} / \mathrm{l}$, mikä vastaa määrää $4 \mathrm{~kg} / \mathrm{ha}$. Tästä sadon korjuun jälkeiseen näytteenottoon oli havaittavissa pienoinen trendi liukoisen typen pitoisuudessa, mutta ero oli vain $1 \mathrm{mg} / \mathrm{l}$ eli $2 \mathrm{~kg} / \mathrm{ha}$, mikä on olematon. Syksyllä kerroksittain otettujen näytteiden (tietoja ei näytetty) perusteella ei ollut havaittavissa typen kulkeutumista syvempiin kerroksiin. Näillä perusteilla voidaan päätellä, että riski typen huuhtoutumisesta ympäristölainsäädännön ja ympäristötukijärjestelmän (MMM 2007, 2008) ehtojen mukaisesti levitetystä turkiseläinten lannasta tai niistä johdetuista lannoitevalmisteista on pieni, vaikka sato jäisikin pieneksi.

Jälkivaikutuskokeen tulosten perusteella turkiseläinten lantojen typpilannoitusvaikutus käyttöä seuraavana vuonna vastasi enimmillään $5,3 \mathrm{~kg}$ N/ha käyttöä seuraavana vuonna kylvölannoituksen yhteydessä mineraalilannoitteena annettuna, joka vastaa noin $130 \mathrm{~kg} \mathrm{~N} / \mathrm{ha}$ mineraalilannoitteen typen jälkivaikutusta. Turkiseläinten lantojen vaikutukset seuraavan vuoden satoon olivat siten olemattomat. Tämänkin perusteella voidaan olettaa, että käytetyistä lantamääristä ei aiheudu oleellista typen huuhtoutumista syksyn ja talven aikana.

\section{Johtopäätökset}

Ohran ja mitä ilmeisimmin muidenkin kevätkylvöisten viljojen lannoituksessa turkiseläinten lannalla tai siitä johdetuilla lannoitevalmisteilla on oleellista riittävä starttityppilannoitus. Se annetaan kylvön yhteydessä kylvölannoittimella sijoittaen. Pelkän lannan ja siitä johdettujen lannoitevalmisteiden käyttö johtavat siihen, että maan nitraattityppipitoisuus jää kasvukauden alussa pieneksi, mistä seuraa se, että ohra kärsii typen puutteesta, mikä puolestaan johtaa sadonalennukseen. Riittävän starttitypen määrä on noin 2/3-osaa liukoisen typen tavoitemäärästä.

Lanta-analyysinmenetelmät, 1:60-vesiuutto ja orgaanisten lannoitteiden 1:100-vesiuutto antavat 
realistisen kuvan turkiseläinten lantojen ja niistä valmistettujen lannoitevalmisteiden typen lannoitusvaikutuksesta. Sen hyödyntäminen edellyttää kuitenkin vastaavan levitysmenetelmän käyttöä, jota käytetään verranteena olevan mineraalilannoitteen levittämiseen. Levitysmenetelmällä on ratkaisevampi merkitys kuin liukoisen typen lähteellä, koska sijoittaminen vähentää lannan ammoniumtyppipainotteisuuden liukoisen typen käyttökelpoisuuden nopeutta vähentävää vaikutusta.

Ainakin pelletit ovat niin pitkälle jalostettu tuote, että ne tulkitaan lannoitevalmisteeksi. Lannoitevalmistestatuksesta on viljelijälle se etu, että se johtaa ravinteiden, erityisesti fosforin, aliarvostukseen nykyisessä ympäristötukijärjestelmässä, mikä puolestaan mahdollistaa todellisten suurempien ravinnemäärien käytön kuin raakalantana. Pellettien suuri kokonaistypen määrä rajoittaa niiden levitysmäärä. Toisaalta niiden käyttö ainoana typen lähteenä ohralla ei ole mielekästä. Pelleteissä on myös runsaasti fosforia, joten ne sopivat nimenomaisesti fosforilannoitteeksi. Koska lannoitevalmisteiden ravinnepitoisuudet ovat paremmin tiedossa, niillä saavutetaan myös paremmin tavoitteen mukainen lannoitus. Kun turkiseläinten lanta kerätään hallikasvatuksessa lietelantana niin, että sen typpi ei pääosin haihdu $\mathrm{NH}_{3}$ :na ilmaan, se sisältää varsin kohtuullisen määrän fosforia suhteessa typpeen.

Turkiseläinten lantojen tyypilliset levitysmäärät ovat varsin pienet levitettäväksi tasaisesti tavanomaisilla lannanlevityslaitteilla. Pellettejä voitaisiin potentiaalisesti levittää esimerkiksi keskipakoislevittimillä, mutta niillä tehtävään levitykseen levitysmäärät ovat suuria. Kotitalouskäytössä ja muuten pienillä aloilla levitys voitaisiin tehdä käsin vastaavalla tavalla kuin näissä kenttäkokeissa. Ammattimainen käyttö edellyttäisi tarkoitukseen sopivan koneen kehittämistä. Turkiseläinten lantaa voitaisiin käyttää myös muiden lantojen väkevöimiseen, jolloin seos olisi levitettävissä tavanomaisilla lannanlevittimillä. Nestemäiset jakeet voidaan sekoittaa esimerkiksi muiden eläinten lietelantaan ja sijoittaa. Seoksissa ravinnesuhteet voisivat myös olla sopivammat kasvinravitsemuksen kannalta.

\section{Kirjallisuus}

Kapuinen, P., Salo, T. \& Paavola, T. 2012. Orgaaniset lannoitevalmisteet ohran typen lähteenä. Julkaisussa: Maataloustieteen Päivät 2012 [verkkojulkaisu]. Suomen Maataloustieteellisen Seuran julkaisuja no 28. Toim. Nina Schulman ja Heini Kauppinen. Viitattu 9.12.2013. Julkaistu 15.1.2012. Saatavilla Internetissä: www.smts (Orgaaniset lannoitevalmisteet ohran typen lähteenä). ISBN 978-9519041-56-8.

Kapuinen, P. 2014. Turkiseläinten lanta porkkanan kasvinravitsemuksessa. Tässä julkaisussa.

Kemppainen, E. 1989. Nutrient content and fertilizer value of livestock manure with special reference to cow manure. Annales Agriculturae Fenniae 28, 3: Annales Agriculturae Fenniae. Seria Agrogeologia et -chimica, University of Helsinki, Helsinki, Diss., 163 - 284.

MMM 2002. Eläinjätestrategia vuoteen 2007. Työryhmämuistio 2002:17. 46 s.

MMM 2007. Maa- ja metsätalousministeriön asetus maatalouden ympäristötuen perus- ja lisätoimenpiteistä ja maatalouden ympäristötuen erityistuista 503. Annettu Helsingissä 26. huhtikuuta 2007.

MMM 2008. Maa- ja metsätalousministeriön asetus maatalouden ympäristötuen perus- ja lisätoimenpiteistä ja maatalouden erityisympäristötuista annetun maa- ja metsätalousministeriön asetuksen muuttamisesta 157. Annettu Helsingissä 14. maaliskuuta 2008.

MMM 2011. Maa- ja metsätalousministeriön asetus lannoitevalmisteista 24: 1 - 6 + 4 liitettä. Annettu Helsingissä 1. syyskuuta 2011.

ProFur 2013. Tilastot. Suomen Turkiseläinten Kasvattajain Liitto Ry. 34 s. Viitattu 8.12.2013. Saatavalla Internetissä: http://www.profur.fi/Tilastoja.

Rekilä, R., Vertanen, P \& Rekilä, T. 2010. Turkiseläintilan ympäristökäsikirja. Päivitetty versio vuodelta 2010. Viitattu 8.12.2013. Saatavilla https://portal.mtt.fi/portal/page/portal/mtt/mtt/julkaisut/turkistilanymparistokasikirja.

Tietohaarukka 2013. Tilastotietoa elintarvikealasta 2013. Ruokatieto Yhdistys ry. 56 s. Viitattu 8.12.2013. Saatavilla Internetissä: $\quad$ http://www.ruokatieto.fi/ruokafakta/tietohaarukka-kattaasuomalaisen-ruokaketjun-pellolta-poytaan.

VN 2000. Valtioneuvoston asetus maataloudesta peräisin olevien nitraattien vesiin pääsyn rajoittamisesta 931. Annettu Helsingissä 9. marraskuuta 2000.

VP 2012. Lantatilasto vuosilta 2005 - 2009. Viljavuuspalvelu Oy. Viitattu 8.12.2013. Saatavilla Internetissä:

http://www.viljavuuspalvelu.fi/sites/default/files/sites/default/files/tilastot/Lantatilasto\%202005\%20\%202009.pdf 